\title{
Voice and Context in Simulated Everyday Legal \\ Discourse: The Influence of Sex Differences and Social Ties
}

\section{Calvin Morrill}

Michelle Johnson

\author{
Tyler Harrison
}

\begin{abstract}
Everyday legal discourse refers to the spoken language with which ordinary people constitute the law-in-action. In this article, we experimentally investigate the social distribution of rule- and relationally-oriented discourse found by ethnographers in small-claims court settings. We examine the influences of sex differences and social ties between disputants on these types of discourse in a mock small-claims setting using a quantitative content coding scheme. We do not find empirical support for sex differences in the production of simulated everyday legal discourse. The relational context of a dispute (operationalized as the strength of social ties between disputants) has significant effects on the distribution of rule- and relationally-oriented discourse, so that disputants in relationally-close contexts produce more relationally-oriented discourse and those in relationally-distant contexts produce more rule-oriented discourses than those in relationally-close contexts. With these findings as a backdrop, we discuss (1) the contextual nature of sex differences in everyday legal discourse; (2) discourse "switching" and emotional investment in personal relationships, and (3) applications for our coding scheme to studies of disputing frames.
\end{abstract}

A

mong the most important developments in sociolegal research is the study of everyday legal discourse used by lay people, for it is through such discourse that law in its many forms often is constituted and enacted. In courtrooms, lay people's everyday legal discourse, in contrast to formal legal discourse, refers to the common voice and argot of the law-in-action: how neighbors, for example, argue their cases in front of a small-claims court judge or how a motorist pleads his case in front of a traffic magistrate. Ethnographers of the lower courts, in particular, often portray the everyday linguistic framing of "legal" disputes in two conceptually distinct but empirically overlapping ways: (1) via a rule-

Earlier versions of this article were presented at the 1994 Law and Society annual meeting, Phoenix, AZ, and the National Communication Association Meetings, Chicago, 1996. We thank Paula England, Scott Jacobs, Sally Jackson, Allan Lind, Linda Molm, William O'Barr, Lynn Smith-Lovin, members of the Social Psychology Seminar at the University of Arizona, and five anonymous reviewers for comments. Direct correspondence to Calvin Morrill, Department of Sociology, Social Sciences Building, University of Arizona, Tucson, AZ 85721 (email calvin@u.arizona.edu).

Law \& Society Review, Volume 32, Number 3 (1998)

(C) 1998 by The Law and Society Association. All rights reserved. 
oriented discourse that frames problems around legal categories and concerns, and (2) via a relationally-oriented discourse that frames problems around appeals to affiliation, relational consequences, and personal needs (Conley \& O'Barr 1990, 1998; Merry 1990; cf. O'Barr \& Conley 1985; Yngvesson 1993). ${ }^{1}$ Such discourses are important because they can affect the processing and outcomes of cases, particularly in small-claims courts where lay testimony is typically a featured (or sole) source of evidence (Conley \& O'Barr 1988). Relationally-oriented discourse generally appears less successful than rule-oriented discourse for achieving disputants' goals and can be treated as "totally irrelevant" by judges (Conley \& O'Barr 1990:81). ${ }^{2}$

At question are the reasons why lay people use particular discourses in court and how such discourses can be effectively analyzed. We conceptualize these questions in relation to the social distribution of everyday legal discourse (e.g., Conley \& O'Barr 1990:78). This approach thus facilitates the study of both the "hard" and "soft" determinisms of language-in-use; specifically, how various kinds of social categories determine everyday legal discourse, as well as how lay people use everyday legal discourse to create and express the social contexts of their disputes (Ewick \& Silbey 1998; Mertz 1992). ${ }^{3}$ Sociolegal scholars have argued that two aspects of the social distribution of everyday legal discourse-"sex and gender differences" and "relational contexts" (e.g., the types of social ties that exist between adversaries)powerfully influence the discourse lay people use in their legal

1 These two kinds of discourse obviously do not capture the only ways ordinary people linguistically frame testimony. Merry (1990), e.g., has observed ordinary people framing their problems in what she calls "moral" and "therapeutic" discourse. Rule- and relationally-oriented discourses, however, appear to be the most common forms of discourse among ordinary people who use the lower courts, and they are the most discussed in the sociolegal literature. At the most abstract level, legal discourses are "stretches of language" (Mertz 1992:413), which range from written forms of legal language, to spoken narrative structures found in plea bargaining (Maynard 1988) and courtroom interactions (Bennett \& Feldman 1981), to ideologies, professional expertise, institutional forms, and "discursive formations" (Foucault 1972, 1979). Everyday legal discourse is generally spoken and emanates from lay litigants.

2 There are conditions, however, that can alter these claims. Jacob (1992; see also Fineman 1991), for example, notes that relationally-oriented discourse is normative in cases in which relationships are at the core of a dispute, such as those involving divorce and child custody. Moreover, the effects of discourse and "speech styles" (on speech styles, see generally O'Barr 1982) on the credibility of testimony may be moderated by the types of settlement forums (e.g., mediation or adjudication) where such language is used (e.g., Morrill \& Facciola 1992).

3 Our focus on the social distribution. of everyday legal discourse does not deny that psychological states (such as stress or apprehension) can influence disputants' language use in court (on the effects of psychological states on language use, see generally Greenberg \& Tannenbaum 1962; Daly 1977). Given that legal access and rates of usage are socially distributed (Black 1976), we suspect that the social distribution of everyday legal discourse may actually condition the kinds of psychological states that various types of people experience in court. 
disputes. ${ }^{4}$ Observational and interview-based studies, however, offer inconsistent evidence of such influences. Jacob (1992:578), for instance, did not find sex differences for everyday legal discourse in his study of custody and child-support cases. Merry (1990:121) observed that men and women shifted easily from rule- to relationally-oriented discourse in their disputes. She also observed that men prefer rule-oriented discourse, while women preferred a more "therapeutic," relationally-oriented discourse (ibid.). At the same time, these same authors observed that disputants shift their legal discourse depending on the relational contexts in which disputes occur. Specifically, disputants tend to use more relationally-oriented discourse in contexts where they have strong social ties with each other and more rule-oriented discourse when they have weak ties with each other (Jacob 1992; Merry 1990)..$^{5}$

In an attempt to further the study of law and language, we investigate for the first time in a controlled environment the effects of sex differences and relational contexts on everyday legal discourse. We use content analysis to quantify the rule- and relationally-oriented components of simulated everyday legal discourse that are produced in response to vignettes that place research participants in a mock small-claims court setting. We first derive theoretical hypotheses about the social distribution of rule- and relationally-oriented discourse from sex difference and relational context perspectives. We then describe the methods and results of an experiment designed to test these hypotheses. Against the backdrop of our findings, we discuss (1) the contextual nature of sex differences in everyday legal discourse; (2) discourse "switching" and emotional investment in personal relationships, and (3) applications for our coding scheme to studies of disputing frames.

\section{A Cultural Sex Difference Perspective on Everyday Legal Discourse}

A vast cultural industry within the popular press trumpets sex differences in the way men and women think, act, and dispute. Deborah Tannen's You Just Don't Understand and John Gray's Men Are from Mars, Women Are from Venus, to name two of the most famous titles of the 1990s, claim that men and women occupy different "gendered cultures." Whether biologically or socially

4 Social class, ethnicity, and educational attainment also influence the production of different forms of legal language (see Conley \& O'Barr 1990:78-81; Berk-Seligson 1990; on the general relationships between social class, ethnicity, and language variation, see Giles \& Coupland 1991; Labov 1980, 1986).

5 See O'Barr (1982:65-69) on other empirical attempts to find systematic linguistic sex differences in legal and organizational dispute resolution. See also Gwartney-Gibbs and Lach's (1994) theoretical model of the relationships between gender roles and the origins, processes, and outcomes of disputes in formal organizations. 
constructed, these cultures, it is argued, often oppose each other, inhibiting cross-sex communication and the formation of lasting relationships.

Many scholarly treatments of sex differences in the social science literature undergird these popular claims and trace their roots to functionalist theories of role acquisition proposed by Parsons and Bales nearly 50 years ago (1955; see the review in Molm \& Hedley 1992). Parsons and Bales argued that males and females acquire different roles through primary socialization: Men are socialized to be goal driven and "task oriented," while women are socialized into "socioemotional" roles oriented toward social relationships. Over the past two decades, cultural feminist and other scholars investigating cross-sex and gendered communication differences in American society have rejected the functionalist trappings of Parsons and Bales, but have carried forth the concern with primary socialization and in particular, the "cultural patterning of linguistic behavior and that of gender relations" (Tannen 1993:5; Lakoff 1975; see the reviews in Aries 1996; Crawford 1995).

Maltz and Borker (1982) provide a particularly clear statement of the cultural approach to discursive sex differences. They argue that in societies where sustained same-sex peer interaction occurs during early childhood, males and females are socialized into gender-specific "cultural" orientations. Specifically, primary socialization establishes early prescriptive and descriptive expectations, scripts, and schemas about gender relations and discourse. Primary socialization, of course, does not automatically produce differences in gender relations and discourse because of the impact of pragmatic and situational constraints on language usage (e.g., Silverstein 1985), but may still condition general patterns of language-in-use among and between men and women. Moreover, the cultural approach does not deny that there are asymmetrical power relations between men and women in contemporary and traditional societies that play important roles in the production of discourse (Tannen 1993; cf. Henley \& Kramarae 1991; Smith-Lovin \& Robinson 1992). Within the cultural perspective, however, primary socialization still sets the baseline for later discourse styles that emerge in interpersonal interaction.

Most classifications of discursive sex differences revolve around differing conceptions of the self that men and women develop (Brown 1993; Goodwin 1993). Gilligan's (1982) arguments about psychological development often resonate with these classificatory differences. She claims that men tend to develop self-concepts as relatively autonomous, self-interested individuals, who are bound by ethical responsibilities to the abstract, moral principles of a hierarchical society. Women, by contrast, develop self-concepts that focus on their responsibilities to peo- 
ple in relationships. In this worldview, society is a web of relational affiliations and concrete obligations. Choices, particularly those involving moral decisions, are relationally-oriented processes for deciding between conflicting obligations to various relationships, rather than commitments to abstract principles. Stated simply, men constantly struggle for status and protect their self-concepts by avoiding failure, while women constantly struggle to preserve interdependence and protect their self-concepts by avoiding isolation (Tannen 1990:25).

In their work on everyday legal discourse in small-claims courts, Conley and O'Barr (1990) draw from these lines of work to speculate about the distribution of rule- and relationally-oriented discourse across male and female disputants. They argue: "We suspect a greater tendency among women to emphasize social relationships over legal rules and a countervailing tendency among men to be oriented toward rules in preference to social considerations in their arguments to the court" (p. 79). These same authors also recognize that women and men do not slavishly obey their primary socialization: Under certain conditions, women and men cross the linguistic-cultural border separating them. In particular, women "can and do approach . . . matters from a rule-oriented perspective ... [resulting from] later role experiences" within educational and business domains (p. 80) and men can adopt relationally-oriented perspectives (see also Merry 1990:121). Thus, these authors admit that the linkage between discourse and sex could be a great deal more complex than identifying a stable set of traits. Nevertheless, the sense left by these works is that sex differences in everyday legal discourse tend to reflect primary socialization into male and female cultures.

Against this backdrop, we expect rule- and relationally-oriented discourse to be differentially distributed across men and women. Specifically, we expect women to use more relationallyoriented discourse than men in their court presentations, whereas we expect men to use more rule-oriented discourse than women in their court presentations.

\section{A Relational Context Perspective on Everyday Legal Discourse}

A second perspective on the social distribution of discourse locates language production in social contexts and situations that enable and constrain discourse patterns. This perspective builds on the claim that speakers have communicative repertories enabling them (sometimes consciously, sometimes habitually) to express the same ideas in a variety of different ways according to the requirements for pragmatically effective communication in particular social contexts (Giles \& Coupland 1991:3-20; Gum- 
perz 1982). Applied to everyday legal discourse, these ideas suggest that the social contexts in which disputes arise can influence the ways that people communicate their grievances both within and outside of legal forums. Everyday legal discourse is thus socially grounded in the pragmatics and creativity of speakers, yet is not "somehow free of the strong constraints" set by social structure (Mertz 1992:419).

Among the most salient social contextual considerations for language usage is the strength of social relationship (tie) that exist between actors (e.g., Scott \& Lyman 1968; McLaughlin, Cody, \& Robey 1980). As conceived by Granovetter (1973:1361), the strength of a social relationship consists of a "combination of the amount of time, the emotional intensity, the intimacy (mutual confiding), and the reciprocal services which characterize the tie." Subsequent empirical investigations have determined that the least confounded and clearest indicator of interpersonal tie strength is emotional intensity or what is commonly referred to as the relational "closeness" between actors (Marsden \& Campbell 1984). ${ }^{6}$

In general, relational closeness appears to suppress the invocation of legal rules in dispute processing and conflict management, while under conditions of relational distance, "rules will dominate the proceedings" (Black 1993:146). Jacob (1992) further elaborates the mechanism by which relational closeness operates on disputing. He argues that having a future orientation in close relationships has profound effects on how people frame and manage their disputes: "It is well known, for instance, that when disputants are acquaintances or have a stake in their future relations, they may behave differently than when they are complete strangers. As strangers, they are less constrained by social norms" (p. 569; see also Ellickson 1991). In such contexts, disputants may be likely to draw on legal norms to fill in the normative "blanks" in their interaction. The normative "shadow of the law" (Mnookin \& Kornhauser 1979) therefore is longer for disputants without strong social ties and shorter for disputants who have strong social ties. These arguments also are congruent with Merry's (1990:121) observations that men and women readily shift from rule- to relationally-oriented discourse according to the relational contexts of their disputes.

From a relational context perspective, therefore, we expect rule- and relationally-oriented discourse to be differentially distributed across interpersonal ties of varying closeness. Specifically, we would expect relationally-close disputants to use more relationally-oriented discourse in their court presentations than rela-

6 This conceptualization of tie strength is based on the contents of social relations. An alternative way to measure tie strength is the form that a social relation takes; for example, its symmetry or asymmetry as illustrated by whether actors mutually express affiliation or exchange goods and services with each other (see generally Friedkin 1980). 
tionally-distant disputants. At the same time, we expect relationally-distant disputants to use more rule-oriented discourse in their court presentations than relationally-close disputants.

\section{Research Design and Methods}

We conducted an experimental study in which male and female participants were randomly assigned (in roughly equal proportion) to one of two tie-strength conditions: a condition in which they were relationally close to their adversary and one in which they were relationally distant. In the study, we asked participants to read a vignette that described several events leading up to a small-claims court case and to imagine themselves as the plaintiff in the case. We then asked each subject to write a script for how they would present their case to a small-claims court judge. Our dependent variable is the quantity of rule- and relationally-oriented discourse measured as the proportion of ruleand relationally-oriented words within each presentational script.

\section{Participants}

We recruited 20 undergraduates from a variety of upper-division undergraduate courses in a large southwestern university to participate in a pilot study to generate preliminary presentational scripts and to pilot test our materials, questionnaires, and coding procedures. We used 12 of these scripts for coding training and 8 for our initial reliability estimates reported later in this section. We then recruited participants $(n=82)$ from a variety of upperdivision social science courses. Recruitment incentives for participants derived from the opportunity to earn extra credit in their classes and their interest in law and language. Prior to beginning our coding for the actual study, we randomly selected 10 participants' presentational scripts (balanced on gender) for use in a reliability analysis midway through the coding, using the remaining 72 scripts for the actual study. In the main study, 39 participants were female and 33 were male. Participants' ages ranged from 18 to 43 years with a mean age of 23 years. The ethnic makeup of the sample was $80.9 \%$ European American, $8.6 \% \mathrm{La}$ tino, 4.9\% African American, 4.3\% Asian American, and 1.4\% Native American. ${ }^{7}$

7 For certain experimental purposes, such as the investigation of expert decisionmaking, using undergraduates as participants may be unjustified. We believe that the use of advanced undergraduates in the present context is justified because our investigation focuses on how lay populations produce legal discourse. However, we are not under the illusion that participants in our study represent how people of very different education levels, ages, ethnicities, and experiences produce legal discourse. We view our attempts reported here as an effort to generalize about the theoretical perspectives discussed in the previous section rather than about the population at large. For a brief review of the use of experts and undergraduates in law and language experimentation, see Morrill \&c Facciola 1992:n.15. 


\section{Cases and Manipulation 8}

We constructed vignettes for our small-claims court cases via a multistage process. First, we conducted a literature search of the research on informal courts for typical issues and case logics underlying disputes involving individuals (e.g., Conley \& O'Barr 1988; Rhunka, Weller, \& Martin 1978; Whelan 1990; Yngvesson \& Hennesey 1974-75). Second, we informally surveyed students currently enrolled in several advanced undergraduate sociology and communication courses about the typical kinds of smallclaims court cases they had been involved with or with which they were familiar. Third, the first author informally interviewed local small-claims court judges $(n=4)$ about the kinds of cases they typically heard that involved members of our study population. Fourth, we abstracted types of cases and defendants which we believed could be plausibly manipulated in our experimental conditions and understandable to participants from our study population.

We developed two vignettes to which we believed members of our study population could relate. Both vignettes involved common interpersonal "debt cases," in which one person owes another person money. Our first vignette involves two college roommates. The participant (the eventual plaintiff) in the case lends his or her roommate (the gender is left unspecified) $\$ 300$ for rent with the explicit understanding that the roommate will pay the money back in a short period of time. The participant never receives payment, and the roommate moves out of the plaintiff's apartment. After numerous failed attempts to be paid back, the participant decides to take the ex-roommate to smallclaims court. Our second vignette involves two neighbors. In this case, the participant lends his or her computer printer to a neighbor when the neighbor's printer breaks down. The neighbor spills coffee on the printer, shorting it out and ruining it. The participant and the neighbor agree that the printer is worth $\$ 300$, and the neighbor agrees to reimburse the participant for the cost of the printer within a short period of time. The participant never receives payment. After numerous failed attempts to be paid back, the participant decides to file a small-claims cases against the neighbor.

We manipulated tie-strength conditions by varying the relational distance between the participant and the imagined defendant. In the relationally-close condition, participants were instructed to imagine the defendant as someone with whom they

8 We used written transcripts in our experiments because of previous findings that indicate written stimuli in law and language experiments do not differ significantly in their effects from auditory stimuli. Moreover, the use of written stimuli enabled us to gain control over other sources of variation, such as nonverbal communication or judges' characteristics (see generally Erickson et al. 1978; Vinson \& Johnson 1989). 
have regular contact, feel emotionally close (i.e., either a neighbor or a roommate they knew well), have friends in common, and with whom the participant wants to preserve a relationship. In this way, we introduced a future relational orientation between the disputants within the relationally-close condition. ${ }^{9}$ To facilitate this process, participants in the relationally-close condition were asked to place the initials in the blanks provided in the vignette of an actual person to whom they feel strongly attached, with whom they have a future relational orientation, and who is either a neighbor or a roommate. In the relationally-distant condition, participants were asked to imagine the defendant as being either a new roommate or a neighbor with whom they had experienced little contact. The Appendix presents the vignettes used in the study.

In both cases, we minimized other aspects of small-claims court cases that occur in many empirical examples of informal court processing, such as consulting with an attorney prior to filing or threatening the defendant (e.g., Merry 1990). Although these components could add a greater degree of realism to the vignettes, we believe they might also threaten the internal validity of the study.

We also recognize the potential confound in the way we manipulated the tie-strength conditions in our vignettes. By asking participants to think of an actual person who would fit the description of a relationally-close neighbor or close roommate, we could have introduced a plethora of unmeasured variables into the manipulation. However, our pilot tests of vignettes without the initials of a relationally-close person yielded inconsistent perceptions on the social tie manipulation. Participants also perceived more socially intimate adversaries, such as family members, as highly implausible adversaries to the point that many could not complete their presentational scripts. ${ }^{10}$ Our strategy for manipulating the tie-strength conditions also meant that there are additional differences in the vignettes aside from the manipulation. To create a plausible situation in which a person would lend money or a printer to a person to whom they were weakly tied required that some additional context be built in to the relationally-distant condition. For example, the relationallydistant roommate vignette begins with some background on how two previously unacquainted individuals became roommates. We feared that such background information could be perceived by participants as overly contrived. However, in college settings, such liaisons and financial difficulties are quite common among

9 We thank Allan Lind for suggesting the importance of this aspect in our manipulations.

10 It is not surprising that participants experienced difficult imagining suing a close family member given general claims about the "inactivity" of law between extreme intimates (Black 1976:41). 
people who barely know each other (Moffat 1989). Our analyses of the participants' perceptions of the vignettes' realism further substantiate this claim.

\section{Procedures}

Participants reported to a study called "Legal Experiment" and were told that the purpose of the study was to investigate how people present their cases in court. They were then given packets containing the following materials: (1) background information about the typical procedures in small-claims court, (2) a case vignette, (3) instructions and pages for writing a presentational script related to the vignette, and (4) a questionnaire. The questionnaire was arranged in the following order:

1. Five true-false questions used to check the participants' comprehension of the main substantive elements of the vignette.

2. Five 7-point semantic differential items used to measure the participants' perceived relational context (tie strength) with the defendant in the vignette. The adjectival pairs were distant-close, strong-weak, disloyal-loyal, personal-impersonal, familiar-unfamiliar.

3. Three questions to assess the realism of the case from the participants' perspective. Responses to these questions were scaled on four 7-point semantic differential items to capture $(a)$ how realistic they felt the case was (realisticunrealistic), $(b)$ whether they had ever experienced a situation similar to the one depicted in the vignette (neveroften), and ( $c$ ) how likely they would be to sue if they actually experienced the events depicted in the vignette (likely-unlikely).

4. Demographic questions on sex, ethnicity, and family income.

5. Questions used as covariates about the participants' experience in actual court cases (measured as no experience, experience as a principal or witness in one case, experience as a principal or witness in more than one case) and legal-oriented television programs, such as LA Law, People's Court, or Top Cops (measured as not at all, one to three hours per week, more than three hours per week).

Participants were instructed at two points in the materials to write their scripts in their own words as they would actually present the case if they found themselves in the situation described in the vignette. Participants also received instructions that they would have as much time as necessary to prepare their presentational script, but that they should design their script so that it would take no longer than 5-7 minutes to present to a judge. We constrained the time of presentations in order to keep the scripts 
at a manageable length for coding purposes, recognizing that such time constraints would produce far shorter scripts than most of the naturally occurring texts contained in Conley and O'Barr (1990).

\section{Coding Rule- and Relationally-Oriented Discourses}

Conley and O'Barr (1990:181-85; see also Mertz 1992:430) eloquently discuss the difficulties of quantifying rule- and relationally-oriented discourses either through global coding (classifying a litigant's entire testimony as having one or the other orientation) or componential coding (classifying small segments of discourse-counting words-from litigant testimony to arrive at statistically based judgments about discourse orientation). They note that discourse often contains multiple orientations as speakers switch back and forth from relational to legal concerns. They further observe that litigants often mean different things when they use rule- and relationally-oriented discourses. Conley and O'Barr (p. 182) illustrate this situation by noting that a litigant could make numerous references to how a breach of contract negatively affects his or her personal life only to later dismiss the concern as irrelevant. The appearance of personal consequences in this litigant's discourse, Conley and O'Barr argue, would not necessarily make this discourse relationally oriented. Furthermore, judges' orientations to disputes also affect the pragmatics and perceptions of everyday legal discourse: What can sound like rule-oriented discourse to a relationally-oriented judge can sound like relationally-oriented discourse to a rule-oriented judge.

It is clear from this brief discussion that there are several encumbrances to the development of a meaningful quantitative coding scheme that could handle all these concerns. Our goal is less ambitious and focuses primarily on the overt manifestations of rule- and relationally-oriented discourse. We rejected global discourse coding as too coarse a procedure for present purposes, believing that a componential coding strategy could provide a step toward a quantitative portrait of the multifaceted, behavioral nature of everyday legal discourse. The closest cousin to our strategy appears in the ethnographic literature on "unitizing" the substantive contents found in textual field data (e.g., field notes, discourse, narratives; Lincoln \& Guba 1985:332-56; see also Emerson, Fretz, \& Shaw 1995; Manning \& Cullum-Swan 1994). To unitize is to "disaggregat[e textual] data into the smallest pieces of information that may stand alone as independent thoughts in the absence of additional information other than a broad understanding of the context. . . A unit may consist of a few words, a complete sentence, several sentences, or an entire paragraph" (Erlandson 1994:117). For present purposes, a unit 
of rule- or relationally-oriented discourse is the smallest piece of information that can stand alone as an independent expression of a rule or relational orientation." " Our context consists of (1) the experimental conditions created with the vignettes and (2) each subject's presentational script.

The categories for our coding scheme derive from Conley and O'Barr's (1990) empirically grounded discussions of ruleand relationally-oriented discourses, readings of the naturally produced texts included in their study and other studies (e.g., Merry 1990; Yngvesson 1993), and our initial codings of the scripts produced by participants in the pilot study. The rule-oriented categories capture several core aspects of legal discourse: prima facie elements (references to the essential facts of the case), contracts (references to explicit contracts, agreements, or deals that specified the terms of the loan), relevant laws (references to a law that supports the plaintiff's case), ${ }^{12}$ legal rights (references to rights that the plaintiff claims are guaranteed by or found in law), liability for the money or damaged possession (references to legal responsibility of the defendant to repay the loan), and legal remedies (requests by plaintiffs for the court to rule in their favor congruent with legal norms). In addition, we included formal legal labels (e.g., "defendant," "plaintiff") as an element of rule-oriented discourse because such labels typify the formality found in official, legal discourse (and following the practice in Conley \& O'Barr 1990).

In addition to the sources mentioned above, we drew on a number of literatures as we constructed our relational closeness subcategory, including research on personal relationships (Blumstein \& Kollock 1988); relational development, dissolution, and commitment (Duck 1982; Duck \& Pittman 1994; Knapp 1983); and social exchange theories of interpersonal relations (Foa \& Foa 1980; Kelley \& Thibaut 1978). Relational closeness specifically captures references to emotional commitment, including trust, invented relational history (beyond the sketch provided in the relationally-close condition vignettes), and consequences for the relationship as a result of the dispute. Our other relationally-oriented subcategories were personal motivations (references to why the plaintiff helped out the defendant in the first place), personal consequences (references to hardships that the plaintiff has suffered as a result of the dispute), attributions for noncompliance (references to psychological motivations for why the defendant has

11 Our coding approach therefore should be distinguished from, and has less ambitious goals than, discourse or conversational analysis in which the goal is to understand the "machinery of conversation" or, in less metaphorical terms, "the practices and common sense reasoning processes by which conversationalists display and recognize" social order (Jacobs 1987:438).

12 We were less concerned whether the plaintiff accurately quoted or used technically relevant laws in arguing their case than that they invoked something they called "law" at all. 
not repaid the plaintiff), personalization of the adversary (using informal nicknames, attributions of gender), collective pronouns (using "we" or "us" when describing interactions between the plaintiff and the defendant), and relational remedies (requests directed toward the judge that focus on validating relational rather than legal norms).

We coded the participants' presentational scripts into ruleand relationally-oriented components by unitizing each script into the smallest meaningful phrases, sentences, and labels corresponding to each coding subcategory. We then counted the number of words in each subcategory to arrive at percentage distributions for each category within each script. Table 1 contains each of these coding categories and examples of rule- and relationally-oriented textual units drawn from presentational scripts.

Table 1. Coding Categories and Illustrations for Rule- and RelationallyOriented Discourse from Respondent Scripts

Discourse Type \& Coding

Category Illustrations ${ }^{\mathrm{a}}$

Rule-oriented discourse"

(1) Reference to prima facie elements of the dispute.

(2) Reference to contracts between the two parties.

(3) References to questions or statements about the law and legal processes (e.g., reference to a specific law or to evidence that will be produced).

(4) References to legal liability of the other defendant for damages.

(5) Reference to legal rights.

(6) Using legal and formal labels for self and adversary ("defendant" or "plaintiff"

(7) Requests for legal remedies (e.g., compensation) made to the judge.
"[The defendant] had a paper to print out and [his] printer was broken. I let [him] use my printer. While it was printing, [the defendant] spilt coffee in my printer."

“. . . [he] didn't have the rent for that month so I lent him the money. ..."

"[The defendant] and I made an oral contract about when the rent would be paid ... and for how much."

"[We] had a legally binding agreement about him paying me for the printer."

"There's a law against people not paying their debts. The law is clear that people have to pay their loans back."

"As you can see, [the defendant] was definitely the reason why my printer is broken. [He] should be responsible for it being repaired."

"It is my right to be paid the rent that is owed to me."

"I know my rights in this case. I have a right to be paid for the broken printer."

See examples throughout Table 1

Your Honor, I ask you to make [the defendant] pay the damages for my broken printer."

"Judge, I want to be compensated for the rent owed to me by [the defendant]." 
Table 1-Continued

Discourse Type \& Coding

Category

Illustrations $^{\mathrm{a}}$

Relationally-oriented discourse

(8) Reference to a characteristic of emotional closeness, including trust, emotions, invented relational history (over and above that given in the vignette), and consequences for the relationship as a result of the situation portrayed in the vignette.

(9) Reference to personal motivations for interacting with the other party prior to the dispute (beyond that given in the vignette).

(10) Reference to personal consequences as a result of interacting with the other party (beyond that given in the vignette).

(11) References to psychological attributions for noncompliance by the other party.

(12) Personalization of the other party, including attributions of gender, the use of nicknames, or other informal labels.

(13) Using collective pronouns when describing interactions between self and the other party (e.g., "we" or "us")

(14) Requests for relational remedies made to the judge (e.g., asking the judge to "mediate" between self and the other party or to tell them that "friends do not renege on agreements with friends," etc.).

"[We're] really close. I've known [her] for a long time."

"I really trust [her] and like [her] a lot."

"[We] hang out a lot and go over to each other's places all the time. I really trust [him] as a friend."

"I really fear that our relationship may be on the rocks because of this."

"I hope this problem doesn't put some distance between us."

"There were other things that I needed to be doing at that time, but I decided to do [her] this one favor." (i.e., lending the printer)

“. . I I wanted to help [him] out with the rent ... because it made feel good doing this for a friend."

"I really need the money from her because I have a lot of homework to do. . . I need that printer from her...."

"Without getting the rent money from him, I'm really hurting to pay rent myself."

“... [she's] betrayed me because [she's] a jerk . .."

"I think [he's] mad at me for something else. I can't figure it out otherwise."

See examples throughout Table 1

See examples throughout Table 1

"This is something a good friend does not do to a good friend. Can you tell [initials of a good friend] this too.

"Maybe you could get [her] to sit down and work out some of the anger between [us]."

${ }^{2}$ Illustrations of rule- and relationally-oriented discourse are representative of each subcategory in the presentational scripts.

We then used a multistage process to assess the validity and reliability of the coding scheme. After initial training (conducted by the first author) and discussions among all three authors using the 12 presentational scripts from the pilot study, all three authors independently coded the remaining 8 scripts selected from the pilot study. We computed a Cohen's Kappa coefficient to assess the reliability of these codings by comparing word by word across each pair of coders (Keppel 1982). This analysis 
yielded a Kappa coefficient of .74. After this initial round of coding, we also held several meetings to discuss our coding discrepancies, the majority of which occurred between subcategories within the rule- and relationally-oriented categories. We also discussed the validity of our codings, comparing the experimental scripts and operational definitions of the coding categories with the discussions in Conley and O'Barr (1990). These discussions resulted in some modifications to the coding scheme, which we incorporated in our coding of the 82 scripts generated in the actual study. At this point, 72 of the 82 scripts were distributed in roughly equal proportion to each of the three authors for coding. We held back 10 scripts for another reliability check midway through our coding, which yielded a Kappa coefficient of .84.

\section{Results}

\section{Preliminary Analyses}

The seven-item scale used to assess relational context achieved a Cronbach's alpha interitem reliability of .88. A manipulation check on the ratings of relational context for the relationally-close $(\bar{x}=5.75 ; 7=$ a very strong perceived social tie and 1 $=\mathrm{a}$ very weak perceived social tie) and relationally-distant $(\bar{x}=$ 2.89 ) conditions revealed that the participants could readily and accurately discriminate between the two $(F(1,70)=115.3, p<$ $.001)$. Furthermore, an average correctness rate of $93 \%$ on the five true-false questions regarding the substantive facts for each vignette provides solid evidence that the participants closely read and understood the information in the vignettes.

Participants judged the vignettes to be relatively realistic $(\bar{x}=$ $5.71 ; 1=$ unrealistic and $7=$ realistic $)$, reported that they had not been involved in situations similar to the ones depicted in the vignettes very often $(\bar{x}=2.59 ; 1=$ rarely and $7=$ often $)$, and claimed that they would be somewhat unlikely to sue in actual situations similar to those depicted in the vignettes $(\bar{x}=3.9 ; 1=$ unlikely to sue and $7=$ likely to sue). The unlikeliness for participants to sue emerged as particularly pronounced in the relationally-close conditions (for relationally-close condition, $\bar{x}=2.97$; for relationally-distant condition, $\bar{x}=4.97 ; F(1,70)=19.02, p<$ $.001) .^{13}$

\section{Overall Descriptive Statistics for the Scripts}

Presentational scripts ranged in length from 51 to 274 words $(\bar{x}=125$; s.d. $=39.57)$. Neither male nor female presentational scripts differed substantially in length from the overall script

13 This preliminary finding again conforms to the general relationship between law and social intimacy (see note 11 ). 
lengths. Male scripts ranged from 60 to 214 words $(\bar{x}=116$; s.d. $=$ 42.48). Female scripts ranged from 62 to 220 words $(\bar{x}=119$; s.d. $=36.08)$. As with the gendered scripts, the script lengths did not differ substantially in the social-tie conditions from those in the overall sample. Scripts in the relationally-distant condition ranged from 58 to 222 words $(\bar{x}=115$; s.d. $=38.67)$. Scripts in the relationally-close condition ranged from 51 to $215(\bar{x}=114$; s.d. $=$ 41.33).

We calculated mean percentages across the scripts for each subcategory to standardize our comparison of words devoted to rule- and relational-discourse across the scripts. This strategy controlled for the possibility that the idiosyncratic verbosity of a few participants would affect the results of the study. The mean percentage of words contained in each subcategory across scripts ranged from a high of $27.6 \%$ in prima facie elements to a low of $1.3 \%$ for relevant laws (see Table 2). Participants therefore drew

Table 2. Mean Percentages of Rule-Oriented and Relationally-Oriented Words $(n=72)$

\begin{tabular}{lclr}
\hline Rule-Oriented Words & Mean $\%$ & Relationally-Oriented Words & Mean \% \\
\hline Prima facie elements & 27.6 & Closeness & 11.0 \\
Contracts & 10.4 & Personal motivations & 5.7 \\
Legal liability & 6.0 & Personal consequences & 4.3 \\
Legal rights & 4.1 & Attributions for noncompliance & 8.1 \\
Legal and formal labels & 1.9 & Personalization of adversary & 7.5 \\
Relevant laws & 1.3 & Collective pronouns & 1.1 \\
Legal remedies & 8.4 & Relational remedies & 2.6 \\
$\quad$ Subtotal & 59.7 & Subtotal & 40.3 \\
\hline
\end{tabular}

just over one-quarter of the contents of their scripts directly from the facts presented in the vignettes, although the actual range of prima facie elements in the scripts varied dramatically from nearly $70 \%$ to under $20 \% .{ }^{14}$ Participants also added legal elements in their scripts not explicitly mentioned in the vignettes, such as references to "legally binding oral contracts" (contracts, $10.4 \%$ ) They also made explicit requests to the "judge" for legal remedies $(8.4 \%)$ that the court could enforce, including monetary compensation and occasionally punitive damages. To a lesser extent, they referred to the defendant's legal liability $(6 \%)$ and to

14 One reason for the preponderance of prima facie elements relevant to other subcategories could be participants simply repeating the vignettes in their presentational scripts rather than using the vignettes as an informational source from which to construct scripts in their own words. Our comparisons of the scripts with the vignettes indicate that the prima facie elements were not carbon copies of the vignettes. Participants offered their own phrasings for the prima facie elements of the case. The formats of the vignettes, however, did appear to affect the narrative form used by the participants in their scripts by giving participants an inductive picture of the facts in each case. As a result, nearly every subject produced an inductive script. We should note that we purposively constructed the narratives in this manner given the typical use of inductive narratives by lay litigants in small-claims court (O'Barr \& Conley 1985). 
their own "legally guaranteed rights" (4.1\%) for obtaining the "money owed them."

The most prevalent aspects of relationally-oriented discourse found in the scripts fell into the relational closeness subcategory (11\%), including how the plaintiff "trusted" the defendant, aspects of the plaintiff and defendant's relational history, and fears that the dispute could harm the relationship between the plaintiff and the defendant. Plaintiffs often expressed attributions for noncompliance $(8.1 \%)$ as a betrayal of trust or assumed that defendants withheld payment because they were "angry" with plaintiffs. Personalizations of the adversary $(7.5 \%)$ often took the form of using personal, gendered pronouns, as well as providing small, intimate details about the other party. To a lesser extent, participants filled in their own (emotionally based) personal motivations $(5.7 \%)$ for lending the defendant the rent money or the printer and mentioned the personal consequences $(4.3 \%)$ they suffered because of the lack of timely compensation by the defendant. Finally, plaintiffs sometimes asked the judge for relational remedies $(2.6 \%)$ that would "make the defendant apologize" to them or admonish the defendant for "not doing this [withholding repayment] to a friend."

\section{Covariates}

We dichotomized the prior participation variable into no experience or experience as a principal or witness in a legal case because no one in the sample had participated in more than one case. Our analyses revealed nonsignificant relationships between prior participation in the legal system and the amount of ruleoriented $(F(1,70)=.30, p>.05)$ and relationally-oriented discourse $(F(1,70)=.24, p>.05)$ produced by participants. Nonsignificant relationships also emerged for legally-oriented television program viewing and rule-oriented $(F(2,69)=.19, p>.05)$ and relationally-oriented discourses $(F(2,69)=.15, p>.05)$ produced by participants. Finally, the relationships between case contents (printer versus rent) and the amounts of rule-oriented $(F(1,70)=.79, p>.05)$ and relationally-oriented $(F(1,70)=.66$, $p>.05$ ) discourses produced by participants were nonsignificant.

\section{Sex Differences ${ }^{15}$}

We did not find support for the hypothesized relationships between gender and everyday legal discourse. Women did not use more relationally-oriented discourse than men $(F(1,68)=$ $.91, p>.05)$. Nor did men use more rule-oriented discourse than

15 We did not hypothesize differences between components of rule- and relationally-oriented discourse and therefore did not conduct difference means tests for them. 
women $(F(1,68)=.48, p>.05)$. Table 3 contains the distribution of rule- and relationally-oriented discourse across male and female participants. ${ }^{16}$

\section{Social Ties}

We found strong support for the relational context hypotheses. Participants in the relationally-close condition used more relationally-oriented discourse than those in the relationally-distant condition $(F(1,68)=16.14, p<.001)$. Participants in the rela-

Table 3. Mean Percentages of Rule- and Relationally-Oriented Words per Discourse Subcategory by Sex

\begin{tabular}{|c|c|c|c|c|c|}
\hline & \multicolumn{2}{|c|}{$\begin{array}{c}\text { Rule-Oriented } \\
\text { Words (Mean \%) }\end{array}$} & \multirow[t]{2}{*}{ Rela } & \multicolumn{2}{|c|}{$\begin{array}{r}\text { lationally-Oriented } \\
\text { Words (Mean \%) } \\
\end{array}$} \\
\hline & Women & Men & & Women & Men \\
\hline Prima facie elements & 26.1 & 28.3 & Closeness & 12.0 & 12.6 \\
\hline Contracts & 11.0 & 9.1 & Personal motivations & 7.1 & 6.3 \\
\hline Legal liability & 5.7 & 6.0 & Personal consequences & 3.5 & 4.3 \\
\hline Legal rights & 2.3 & 1.9 & $\begin{array}{l}\text { Attributions for } \\
\text { noncompliance } \\
\text { Personalization of }\end{array}$ & 8.8 & 7.9 \\
\hline Legal and formal labels & 2.3 & 2.6 & adversary & 9.2 & 8.1 \\
\hline Relevant laws & 0.8 & 1.1 & Collective pronouns & 0.9 & 1.7 \\
\hline Legal remedies & 8.3 & 8.7 & Relational remedies & 2.2 & 1.2 \\
\hline \multirow[t]{3}{*}{ Subtotal } & 56.5 & 57.7 & Subtotal & 43.5 & 42.3 \\
\hline & $68)=.91$ & $p>.05$ & $F(1$, & $68)=.4$ & $p>.05$ \\
\hline & $n(\mathrm{w}$ & men) $=$ & $n($ men $)=33$ & & \\
\hline
\end{tabular}

Table 4. Mean Percentages of Rule- and Relationally-Oriented Words per Discourse Subcategory by Social Tie Condition

\begin{tabular}{|c|c|c|c|c|c|}
\hline & \multicolumn{2}{|c|}{$\begin{array}{l}\text { Social-Tie } \\
\text { Condition } \\
\text { (Mean \%) }\end{array}$} & & \multicolumn{2}{|c|}{$\begin{array}{l}\text { Social-Tie } \\
\text { Condition } \\
\text { (Mean \%) }\end{array}$} \\
\hline & Close & Distant & & Close & Distant \\
\hline Rule-oriented words: & \multicolumn{5}{|c|}{ Relationally-oriented words: } \\
\hline Prima facie elements & 22.7 & 30.1 & Closeness & 23.2 & 1.2 \\
\hline Contracts & 8.8 & 11.2 & Personal motivations & 8.0 & 6.0 \\
\hline Legal liability & 2.8 & 12.0 & Personal consequences & 6.8 & 2.2 \\
\hline Legal rights & 1.4 & 3.2 & $\begin{array}{l}\text { Attributions for } \\
\text { noncompliance }\end{array}$ & 5.2 & 8.5 \\
\hline Legal and formal labels & 0.9 & 2.8 & Personalization of adversary & 9.1 & 6.1 \\
\hline Relevant laws & 0.0 & 1.9 & Collective pronouns & 3.1 & 1.1 \\
\hline Legal remedies & 3.0 & 7.2 & Relational remedies & 5.0 & 0.0 \\
\hline Subtotal & $\overline{39.6}$ & $\overline{68.4}$ & Subtotal & $\overline{60.4}$ & $\overline{31.0}$ \\
\hline \multicolumn{6}{|c|}{$F(1,68)=16.14, p<.001$} \\
\hline
\end{tabular}

16 Because our dependent variable lacks statistical normality, we normalized the data using an arc sine transformation (Neter, Wasserman, \& Kutner 1990:620-23). $Y^{\prime}=2$ $\arcsin \sqrt{ } Y$, where $Y$ equals the mean proportion of words devoted to rule- and relationallyoriented discourse. The transformed data did not alter the results reported in text. 
tionally-distant condition used more rule-oriented discourse than those in the relationally-close condition $(F(1,68)=17.56, p<$ .001 ). Table 4 contains the mean percentages of rule- and relationally-oriented discourse across the social-tie conditions. ${ }^{17}$

\section{Summary and Discussion}

We explored, in a controlled experiment, the effects of sex differences and relational contexts on the production of simulated everyday legal discourse. Our study provides little support for sex differences in the production of rule- and relationallyoriented discourse. By contrast, the social-tie conditions produced significant differences: Participants in the relationally-distant condition used more rule-oriented discourse than those in the relationally-close condition; participants in the relationallyclose condition used more relationally-oriented discourse than those in the relationally-distant condition. We discuss below the implications of these findings for sociolegal research relevant to sex differences, for emotional investment in relational contexts, and discourse switching, and for the study of dispute frames.

This study joins a growing number of empirical works in the social sciences that question the received wisdom about decontextualized, main-effect sex differences in social interaction (Bogoch 1997; Canary \& Dindia 1998). At issue is not biological, sociopolitical, or economic differences between men and women. Men and women's physiologies certainly differ, just as men and women's social power, social status, and economic stations differ in most societies throughout the world. What scholars (and the present study) question are stereotypical portraits of "womenas-communal" and "men-as-instrumental" (Canary, Emmers-Sommer, \& Faulkner 1997); or in terms closer to the present study, the relationally-oriented "voice" of women and rule-oriented "voice" of men. Canary and Hause (1993), for example, reviewed 15 meta-analyses of sex difference studies $(n=1,306)$ on social interaction. They found that the mean sex effect in these studies accounted for $1 \%$ of the variation in men's and women's behavior. They further argue that their results indicate more similarity than difference in men's and women's communication. In another recent review, Hyde and Plant (1995) argue that there were "zero" to "small" differences between men's and women's psychological orientations to social interaction in $60 \%$ of the studies they reviewed. In $27 \%$ of the studies they reviewed, they found "moderate" effects of sex differences on psychological orientations to social interaction, and in $13 \%$ of the studies, they found "large" effects. At the same time, Eagly (1987) notes that

17 MANOVA analyses to explore interaction effects among sex differences and social ties, and legal discourse did not yield statistically significant results for rule-oriented $(F(1,68)=1.28, p>.05)$ or relationally-oriented discourse $(F(1,68)=1.48, p>.05)$. 
sex differences account for as much variance explained in male and female social interaction as many other psychological and social variables. Rather than casting research on sex differences as an either-or question, therefore, a more useful direction for future sociolegal research should be to investigate the conditions under which sex differences appear in everyday legal discourse.

Here we can suggest some conditions that could influence manifestations of sex differences in the production of rule- and relationally-oriented legal discourse. A point of departure for such considerations is the distribution and activation of cognitive schemata and scripts that men and women hold about sex and gender identities. Although we randomly assigned participants in our experiment to control for individual-level variation and measured a number of potential covariates with our variables of interest, we did not directly measure the gender/sex schemata and scripts held by our participants. If our participant pool included women who consider it important to their self-concept to be stereotypically feminine and men who correspondingly value stereotypical masculinity, significant sex differences in everyday legal discourse would have been more likely. However, the existence of stereotypical beliefs does not guarantee their manifestations unless they are "activated" (Deaux \& Major 1990). To be activated, gender/sex schemata and scripts must be triggered by some feature of a context. Two contextual features appear to be especially relevant for sociolegal research: case contents and thirdparty interaction. Sociolegal researchers have already investigated how substantive issues in cases affect the activation of stereotypically masculine and feminine orientations to disputes. As mentioned at the outset of this article, Jacob (1992) did not observe sex differences in the way disputants framed their approaches during his observations of child custody cases-a context in which one would expect stereotypically masculine and feminine behavior to appear. Other scholars, however, find considerable differences in the orientations of men and women toward cases involving domestic matters (Fineman 1992; Merry 1990). The vignettes in our experiment would not be expected to activate gender schemata given that they focused on debt cases unless one expected that men and women orient themselves differently to debt. This speculation suggests the need for further investigation of how stereotypical sex/gender schemata are triggered.

Another key explanatory variable for sex/gender schemata activation beyond case contents could rest in third-party interaction with litigants. Conley and O'Barr (1990), for example, observed that judges in small-claims courts powerfully influence litigant discourse, often shaping both its content and form. If judges treat male and female disputants in stereotypical ways, such behavior could elicit sex/gender schemata and scripts from disputants. Given the taken-for-granted authority of the adjudica- 
tory institution, disputants could even evaluate such treatment as prescriptive for their own language, thus creating quite pronounced discursive sex differences. This explanation is highly speculative, but is broadly consistent with earlier investigations into the institutional effects of adjudication on the evaluation of legal language (Morrill \& Facciola 1992). Other dispute-processing contexts, such as mediation, could also contain third-party effects on gender schemata activation. For example, a situation could arise in which there is a reluctant male disputant and a relatively forthcoming female disputant. Mediators in the course of enacting the interactional organization and conversational goals of mediation (Garcia 1998) could unintentionally activate stereotypical gender/sex schemata among the disputants by unilaterally addressing the male more often than they address the more forthcoming female disputant, and in so doing seem to favor the male.

Our results also are consistent with ethnographic findings that disputants can shift between rule- and relationally-oriented discourses when in different relational contexts (e.g., Merry 1990:121). However, these findings should be regarded tentatively. Despite our confidence in participants' abilities to discriminate cognitively between relationally-close and distant conditions (as indicated by our manipulation checks and the main results for the study), we have much less confidence that our relational context manipulations created emotionally different situations. In other words, being in a long-term personal relationship creates an emotional commitment that is difficult to induce by simply having participants imagine they are in conflict with a person who fits that role. This idea is significant given that ethnographers of everyday legal discourse argue that emotional investments often fuel relational discourses (Conley \& O'Barr 1990; Jacob 1992; Merry 1990; Yngvesson 1993). In ongoing social contexts, therefore, we would expect current or former emotional investments (whether positive or negative) to affect disputants' abilities to switch between rule discourses and relational discourses. Future research should address explicitly the emotional dimensions of everyday legal discourse.

We also believe that our coding approach can have applications for studying the initial framings of legal problems. During initial framings, people make sense of whether anything injurious has happened to them in a problematic situation and if so, what they want out of the situation, and what actions they are willing to take to achieve their goals (Felstiner, Abel, \& Sarat 1980-81; Horwitz 1990:19-21). Initial framings are typically fragmented and can contain mixes of grievance issues, possibilities, and rule and relational orientations. These orientations, together with other factors (e.g., the use of attorneys and consultation of third parties in informal personal networks), are key for 
determining how and whether people actually use law (Jacob 1992:586; cf. Silberman 1985). Until now, researchers concerned with rule and relational orientations have tended to analyze initial framings using global coding strategies (e.g., Jacob 1992; Merry 1990), although these same researchers recognize that multiple subframes exist within rule- and relationally-oriented discourses which may be important for understanding variation in the mobilization of law. A crucial question becomes not whether one group or type of person uses a rule- or relationallyoriented discourse but what type of rule- or relationally-oriented discourse is used. And subframes carry important implications for the ways people mobilize the law or take extralegal steps to pursue their grievances and disputes (e.g., Felstiner et al. 1980-81; Mirandé 1987). Our approach, therefore, can aid in the identification of subframes within broad types of discourse.

We have attempted here to shed more light on the social distribution of everyday legal discourse by introducing a simulated discourse approach that expands the existing repertory of ethnographic (Conley \& O'Barr 1985, 1990), conversational/discourse (Cobb 1997; Garcia. 1991; Matoesian 1993), and narrative (Ewick \& Silbey 1998; Maynard 1990) approaches for analyzing everyday legal discourse in complementary rather than antithetical ways. These approaches all address the processes through which language constitutes law. For conversational analysts, such processes reside at the micro-interactional level as actors construct and reproduce legal and other orders through talk. For narrative analysts, such processes unfold through the stories that people tell about their experiences using, resisting, and defining the law. For ethnographers, actors produce and interpret everyday legal discourse in local social and cultural contexts. In all these approaches, discourse is an interactional product of ongoing settings. Our approach, by contrast, uses statements collected from actors who were asked to imagine themselves in the role of plaintiffs in a small-claims court case. We recognize the potential shortcomings of using simulated discourse and quantifying discourse. We also recognize the strengths of a simulated discourse approach: It enables aspects of context to be controlled and manipulated, causal relationships between variables to be established, and subcomponents of discourse orientations to be distinguished and aggregated.

It is our impression that future experimental and ethnographic studies in law and language must incorporate interactional processes into experimental studies, as well as more finegrained qualitative and quantitative approaches for coding everyday legal discourse. Such research also must continue to.move in the direction of what Mertz (1992) calls an "integrated approach" to language by examining the relationships between everyday legal discourses and social categories of litigants, social 
contexts, legal issues, and locations within the legal system (e.g., courts, police-layperson encounters, jury deliberations). It is only with such research that we will begin to understand fully the multiple discourses that make up the American legal system, the sources of their variation, and how such voices orient to and mobilize law.

\section{Appendix: Study Vignettes}

\section{Relationally-Close Printer Vignette}

Your long-time close friend, 's printer recently broke down making it impossible to print out a paper that is due the next day. You offer to print out the paper on your printer. brings over a disk with the paper on it. While standing over the printer while the paper is printing out, spills a cup of coffee on the printer, shorting it out. Your repeated efforts to get the printer to work fail, but agrees to repay you $\$ 300.00$ the next week to replace the printer. Several weeks have passed since __ spilled coffee on your printer and none of the money has been paid. You still see socially and share a common set of friends who you and see quite often. You still consider in the future. close friend and want to remain close friends with paid to you. FiNonetheless, the money
nally, you decide to take to small claims court.

\section{Relationally-Distant Printer Vignette}

You've just moved into a new apartment. A few days later, you meet one of your neighbors at a mixer and you get to talking about mutual interests, among them computers. During the conversation, it becomes apparent that your neighbor's printer has broken down making it impossible to print out a paper that is due the next day. You offer to out the paper on your printer. Your neighbor brings over a disk with the paper on it. While standing over the printer while the paper is printing out, your neighbor spills a cup of coffee on the printer, shorting it out. Your repeated efforts to get the printer to work fail, but your neighbor agrees to repay you the $\$ 300.00$ the next week to replace the printer. Several weeks have passed since your neighbor spilled the coffee on your printer and none of the money has been paid. Finally, you decide to take your neighbor to small claims court.

\section{Relationally-Close Rent Vignette}

One month when your long-time roommate and close friend, has financial difficulties, you pay your roommate's $\$ 300.00$ share of the rent. __ agrees to repay you the next week. Several weeks have passed since the time of loan and none of the money has been paid. You are still living with __ and share a common set of friends who you and see quite often. You want __ to continue being your roommate and want to remain close friends with __ in the future. Nonetheless, 
the money has not been paid to you. Finally, you decide to take to small claims court.

\section{Relationally-Distant Rent Vignette}

You need a roommate to share the rent on your apartment and so you place an ad in the local paper. Few people answer the ad, but you finally accept one person. Unfortunately, your new roommate is going through financial difficulties and you pay your new roommate's $\$ 300.00$ share of the rent. Your new roommate agrees to repay you the next week. Since the time of the loan, your roommate got a job on the opposite side of town from your apartment. As a result, your roommate moved out of the apartment to live closer to work. Several weeks have passed since the time of loan and none of the money has been paid. Finally, you decide to take your former roommate to small claims court.

\section{References}

Aries, Elizabeth (1996) Men and Women in Interaction: Reconsidering the Differences. New York: Oxford Univ. Press.

Berk-Seligson, Susan (1990) The Bilingual Courtroom: Court Interpreters in the Judicial Process. Chicago: Univ. of Chicago Press.

Bennett, W. Lance, \& Martha S. Feldman (1981) Reconstructing Reality in the Courtroom: Justice and Judgement in American Culture. New Brunswick, NJ: Rutgers Univ. Press.

Black, Donald (1976) The Behavior of Law. New York: Academic Press.

(1993) The Social Structure of Right and Wrong. San Diego: Academic Press.

Blumstein, Philip, \& Peter Kollock (1988) "Personal Relationships," 14 Annual Rev. of Sociology 467-90.

Bogoch, Bryna (1997) "Gendered Lawyering: Difference and Dominance in Lawyer-Client Interaction," 31 Law $\mathcal{E}$ Society Rev. 677-712.

Brown, Penelope (1993) "Gender, Politeness, and Confrontation in Tenejapa," in Tannen, ed. 1993.

Canary, Daniel J., \& Kathryn Dindia, eds. (1998) Sex Differences and Similarities in Communication: Critical Essays and Empirical Investigations of Sex and Gender in Interaction. Mahwah, NJ: Lawrence Erlbaum Associates.

Canary, Daniel J., Tara M. Emmers-Sommer, \& Sandra Faulkner (1997) Sex and Gender Differences in Personal Relationships. New York: Guilford Press.

Canary, Daniel J., \& Karen S. Hause (1993) "Is There Any Reason to Research Sex Differences in Communication?" 41 Communication Q. 129-44.

Cobb, Sara (1997) "The Domestication of Violence in Mediation," 31 Law $\mathcal{E}$ Society Rev. 397-440.

Conley, John M., \& William M. O'Barr (1988) "Fundamentals of Jurisprudence: An Ethnography of Judicial Decision Making in Informal Courts," 66 North Carolina Law Rev. 467-507.

- (1990) Rules versus Relationships: The Ethnography of Legal Discourse. Chicago: Univ. of Chicago Press.

- (1998) Just Words: Law, Language, and Power. Chicago: Univ. of Chicago Press.

Crawford, Mary E. (1995) Talking Difference: On Gender and Language. Thousand Oaks, CA: Sage Publications.

Daly, John A. (1977) "The Effects of Writing Apprehension on Message Encoding," 54 Jourmalism Q. 566-72. 
Deaux, Kay, \& Brenda Major (1990) "A Social-Psychological Model of Gender," in D. L. Rhode, ed., Theoretical Perspectives of Sexual Difference. New Haven, CT: Yale Univ. Press.

Duck, Steve W. (1982) "A Topography of Relationship Disengagement and Dissolution," in S .W. Duck, ed., Dissolving Personal Relationships. London: Academic Press.

Duck, Steve W., \& Garth Pittman (1994) "Social and Personal Relationships," in M. L. Knapp \& G. R. Miller, eds., Handbook of Interpersonal Communication. 2d ed. Thousand Oaks, CA: Sage Publications.

Eagly, Alice Hendrickson (1987) Sex Differences in Social Behavior: A Social-Role Interpretation. Hillsdale, NJ: Erlbaum.

Ellickson, Robert C. (1991) Order without Law: How Neighbors Settle Disputes. Cambridge: Harvard Univ. Press.

Emerson, Robert M., Rachel I. Fretz, \& Linda L. Shaw (1995) Writing Ethnographic Fieldnotes. Chicago: Univ. of Chicago Press.

Erickson, Bonnie H., E. Allan Lind, Bruce C. Johnson, \& William M. O'Barr (1978) "Speech Style and Impression Formation in a Court Setting: The Effects of Powerful and Powerless Speech," 14 J. of Experimental Social Psychology 266-79.

Erlandson, David A. (1993) Doing Naturalistic Inquiry: A Guide to Methods. Newbury Park, CA: Sage Publications.

Ewick, Patricia, \& Susan S. Silbey (1998) The Common Place of Law: Stories from Everyday Life. Chicago: Univ. of Chicago Press.

Felstiner, William L. F., Richard L. Abel, \& Austin Sarat (1980-81) "The Emergence and Transformation of Disputes: Naming, Blaming, Claiming ... , " 15 Law Ev Society Rev. 631-54.

Fineman, Martha Albertson (1991) The Illusion of Equality: The Rhetoric and Reality of Divorce Reform. Chicago: Univ. of Chicago Press.

Foa, Edna B., \& Uriel G. Foa (1980) "Resource Theory: Interpersonal Behavior as Exchange," in K. J. Gergen, M. S. Greenberg, \& R. H. Willis, eds., Social Exchange: Advances in Theory and Research. New York: Plenum Press.

Foucault, Michel (1972) The Archeology of Knowledge. New York: Harper.

(1979) Discipline and Punish: The Birth of the Prison. New York: Vintage Books.

Friedkin, Noah (1980) "A Test of Structure Features of Granovetter's Strength of Weak Ties Theory," 2 Social Networks 411-42.

Garcia, Angela (1991) "Dispute Resolution without Disputing: How the Interactional Organization of Mediation Sessions Minimizes Argument," 56 American Sociological Rev. 818-35.

- (1998) "The Relevance of Interactional and Institutional Contexts for the Study of Gender Differences: A Demonstrative Case Study," 21 Symbolic Interaction 35-58.

Giles, Howard, \& Nikolas Coupland (1991) Language: Contexts and Consequences. Pacific Grove, CA: Brooks/Cole Publishing Co.

Gilligan, Carol (1982) In a Different Voice: Psychological Theory and Women's Development. Cambridge: Harvard Univ. Press.

Goodwin, Marjorie Harness (1993) "Tactical Uses of Stories: Participation Frameworks within Boys' and Girls' Disputes," in Tannen, ed. 1993.

Granovetter, Mark S. (1973) "The Strength of Weak Ties," 78 American J. of Sociology 1360-80.

Gray, John (1992) Men Are from Mars, Women Are from Venus. New York: Harper Collins.

Greenberg, Bradley S., \& Percy Tannenbaum (1962) "Communicator Performance under Cognitive Stress, " 39 Journalism Q. 169-78.

Gumperz, John J. (1982) Discourse Strategies. New York: Cambridge Univ. Press. 
Gwartney-Gibbs, Patricia A., \& Denise H. Lach. (1994) "Gender and Workplace Dispute Resolution: A Conceptual and Theoretical Model," 28 Law E' Society Rev. 265-96.

Henley, Nancy M., \& Cheris Kramarae (1991) "Gender, Power, and Miscommunication," in N. Coupland, H. Giles, \& J. Wiemann, eds., "Miscommunication" and Problematic Talk. Newbury Park, CA: Sage Publications.

Horwitz, Allan V. (1990) The Logic of Social Control. New York: Plenum Press.

Hyde, Janet Shilbey, \& Elizabeth Ashby Plant (1995) "Magnitude of Psychological Gender Differences: Another Side to the Story," 50 American Psychologist 159-61.

Jacob, Herbert (1992) "The Elusive Shadow of the Law," 26 Law E Society Rev. 565-90.

Jacobs, Scott (1987) "Evidence and Inference in Conversation Analysis," 11 Communication Yearbook 433-43.

Kelley, Harold H., \& John W. Thibaut (1978) Interpersonal Relations: A Theory of Interdependence. New York: Wiley.

Keppel, Geoffrey (1982) Design and Analysis: A Researcher's Handbook. 2d ed. Englewood Cliffs, NJ: Prentice-Hall.

Knapp, Mark L. (1983) "Dyadic Relationship Development," in J. M. Wiemann \& R. P. Harrison, eds., Nonverbal Interaction. Beverly Hills, CA: Sage Publications.

Labov, William, ed. (1980) Locating Language in Time and Space. New York: Academic Press.

- (1986) "Language Structure and Social Structure," in S. Lindenberg, J. S. Coleman, \& S. Nowak, Approaches to Social Theory. New York: Russell Sage Foundation.

Lakoff, Robin (1975) Language and Woman's Place. New York: Harper \& Row.

Lincoln, Yvonna S., \& Egon G. Guba (1985) Naturalistic Inquiry. Beverly Hills, CA: Sage Publications.

Maltz, Daniel N., \& Ruth A. Borker (1982) "A Cultural Approach to Male-Female Miscommunication," in J. J. Gumperz, ed., Language and Social Identity. New York: Cambridge Univ. Press.

Manning, Peter K., \& Betsy Cullum-Swan (1994) "Narrative, Content, and Semiotic Analysis," in N. K. Denzin \& Y. S. Lincoln, eds., Handbook of Qualitative Research. Thousands Oaks, CA: Sage Publications.

Marsden, Peter V., \& Karen E. Campbell (1984) "Measuring Tie Strength," 63 Social Forces 482-501.

Matoesian, Gregory M. (1993) Reproducing Rape: Domination through Talk in the Courtroom. Chicago: Univ. of Chicago Press.

Maynard, Douglas W. (1988) "Narratives and Narrative Structure in Plea Bargaining," 22 Law E Society Rev. 449-81.

McLaughlin, Margaret L., Michael J. Cody, \& Carl S. Robey (1980) "Situational Influences on the Selection of Strategies to Resist Compliance-Gaining Attempts," 7 Human Communication Research 14-36.

Merry, Sally Engle (1990) Getting Justice and Getting Even: Legal Consciousness among Working Class Americans. Chicago: Univ. of Chicago Press.

Mertz, Elizabeth (1992) "Language, Law, and Social Meanings: Linguistic/Anthropological Contributions to the Study of Law," 26 Law E Society Rev. 413-45.

Mirandé, Alfredo (1987) Gringo Justice. Notre Dame, IN: Univ. of Notre Dame Press.

Mnookin, Robert H., \& Lewis Kornhauser (1979) "Bargaining in the Shadow of the Law: The Case of Divorce," 88 Yale Law J. 950-97.

Moffat, Michael (1989) Coming of Age in New Jersey: College and American Culture. New Brunswick, NJ: Rutgers Univ. Press. 
Molm, Linda, \& Mark Hedley (1992) "Gender, Power, and Social Exchange," in C. L. Ridgeway, ed., Gender, Interaction, and Identity. New York: SpringerVerlag.

Morrill, Calvin, \& Peter C. Facciola (1992) "The Power of Language in Adjudication and Mediation: Institutional Contexts as Predictors of Social Evaluation," 17 Law E Social Inquiry 191-212.

Neter, John, William Wasserman, \& Michael H. Kutner (1990) Applied Linear Statistical Models: Regression, Analysis of Variance, and Experimental Designs. 3d ed. Homewood, IL: Richard D. Irwin.

O'Barr, William M. (1982) Linguistic Evidence: Language, Power, and Strategy in the Courtroom. New York: Academic Press.

O'Barr, William M., \& John M. Conley (1985) "Litigant Satisfaction versus Legal Adequacy in Small Claims Court Narratives," 19 Law \& Society Rev. $661-701$.

Parsons, Talcott, \& Robert F. Bailes (1955) Family, Socialization, and Interaction Process. Glencoe, IL: Free Press.

Rhunka, John C., Steven Weller, \& John A. Martin (1978) Small Claims Courts: A National Examination. Williamsburg, VA: National Center for State Courts.

Scott, Marvin B., \& Stanford M. Lyman (1968) “Accounts," 33 American Sociological Rev. 46-61.

Silberman, Matthew (1985) The Civil Justice Process: A Sequential Model of the Mobilization of Law. Orlando, FL: Academic Press.

Silverstein, Michael (1985) "Language and the Culture of Gender: At the Intersection of Structure, Usage, and Ideology," in E. Mertz \& R. J. Parmentier, eds., Semiotic Mediation: Sociocultural and Psychological Perspectives. Orlando, FL: Academic Press.

Smith-Lovin, Lynn, \& Dawn T. Johnson (1992) "Gender and Conversational Dynamics," in C. L. Ridgeway, ed., Gender, Interaction, and Identity. New York: Springer-Verlag.

Tannen, Deborah (1990) You Just Don't Understand: Women and Men in Conversation. New York: Ballantine Books. Press.

Vinson, Larry, \& Craig Johnson (1989) "The Use of Written Transcripts in Powerful and Powerless Language Research," 2 Communication Reports 16-30.

Whelan, Christopher J. (1990) Small Claims Courts: A Comparative Study. New York: Oxford Univ. Press, Clarendon Press.

Yngvesson, Barbara (1993) Virtuous Citizens, Disruptive Subjects: Order and Complaint in a New England Court. New York: Routledge.

Yngvesson, Barbara, \& Patricia Hennesey (1974-75) "Small Claims, Complex Disputes: A Review of the Small Claims Literature," 9 Law $\mathcal{E}$ Society Rev. 219-74. 
